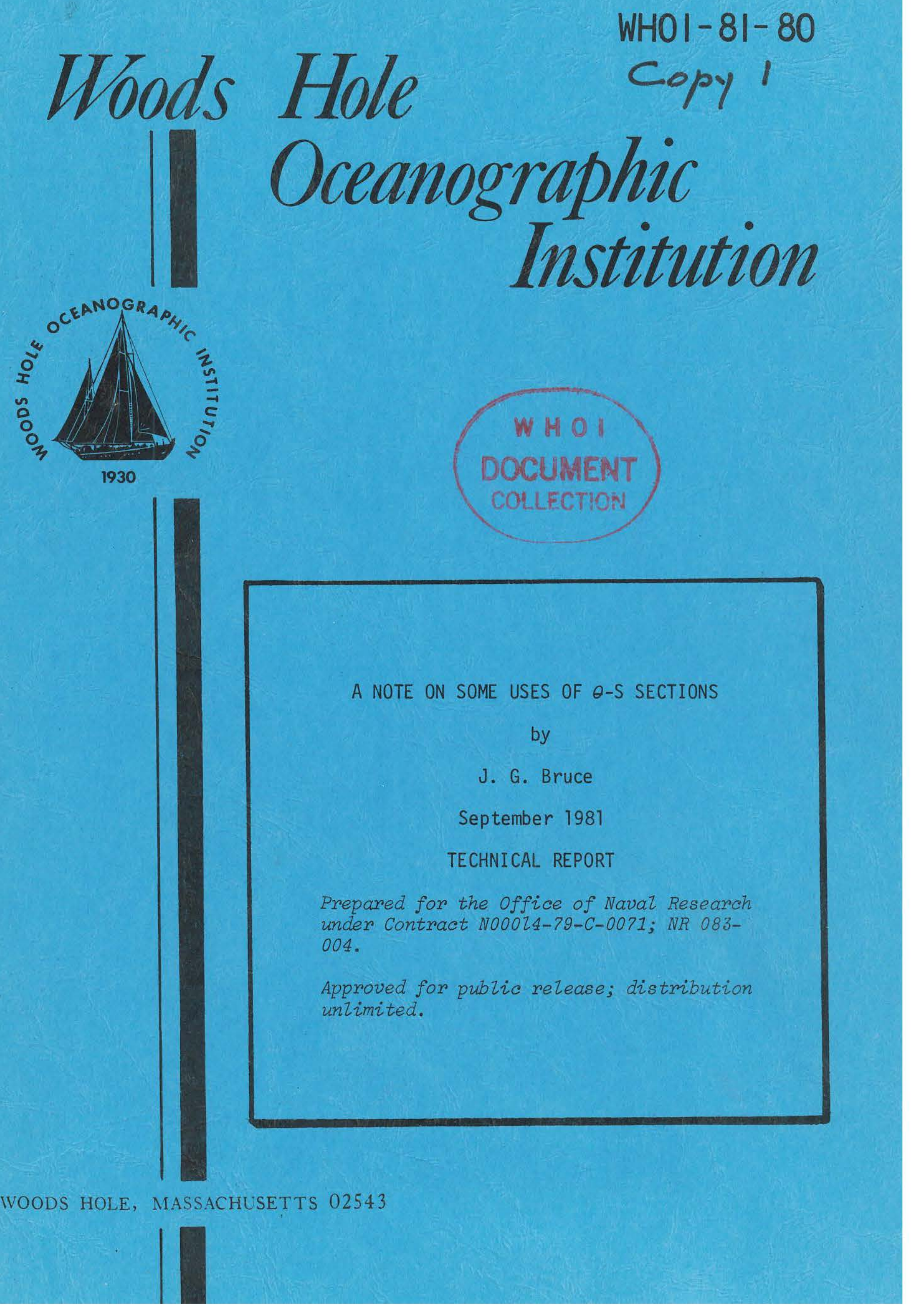


WHOI $-81-80$

A NOTE ON SOME USES OF $\theta$-S SECTIONS

by

J. G. Bruce

WOODS HOLE OCEANOGRAPHIC INSTITUTION

Woods Hole, Massachusetts 02543

September 1981

TECHNICAL REPORT

Prepared for the Office of Naval Research under Contract N00014-79-C-0071; NR 083-004.

Reproduction in whole or in part is permitted for any purpose of the United States Govermment. In citing this report in a bibliogrophy the reference given should be to: Journal of Geophysical Research 86(C7): 6649-6652 (July 20, 1981).

Approved for public release; distribution unlimited.

Approved for Distribution: Valentine Worthington, Chairman Department of Physical Oceanography 


\title{
A Note on Some Uses of $\theta$-S Sections
}

\author{
J. G. BRUCE
}

Woods Hole Oceanographic Institution, Woods Hole, Massachusetts 02543

\begin{abstract}
Isohalines plotted against temperature and horizontal distance along a hydrographic section can be used to observe changes in the T-S or $\theta$-S relationship of water masses. By using this technique, eddies formed off the Somali coast during the southwest monsoon, or Gulf Stream eddies having their own individual T-S characteristics, may be identified.
\end{abstract}

It is sometimes useful to display the changes occurring either spatially or temporally in the temperature-salinity relationship of a type of water. Such can be achieved by constructing a T-S or $\theta-\mathrm{S}$ section in which the isohalines are plotted with temperature and horizontal distance being the coordinates. In regions where no change of $\theta$-S occurs along a section of stations, the isohalines have a zero slope, whereas for large changes the slope would have a high value.

A $\theta$-S section is useful in depicting the near-surface structure such as found in the Somali eddies [Bruce, 1968] in the Indian Ocean formed during the southwest monsoon. Here the relatively fresh $(<35.2 \%)$ coastal water advected northward by the Somali Current becomes entrained in the eddy structure. Figure 1 shows the near symmetry of the characteristics of the prime eddy [Bruce, 1979] (west of approximately $\left.56^{\circ} \mathrm{E}\right)$ about the eddy center $\left(\sim 54^{\circ} \mathrm{E}\right)$. The eddy is anticyclonic, and apparently some mixing along the northern boundary occurred with the warmer more saline water to the north after the eddy turned offshore at $51^{\circ} 30^{\prime} \mathrm{E}$, because the eastern boundary $\left(56^{\circ} \mathrm{E}\right)$ shows an increase in salinity for the same values of temperature. To the east another anticyclonic eddy also is shown centered about $58^{\circ} \mathrm{E}$, again with a slight asymmetry of T-S characteristics caused by mixing of near surface water along its northern edge.

Whereas the southwest monsoon attains full strength during July and August, the weaker northeast monsoon reaches a

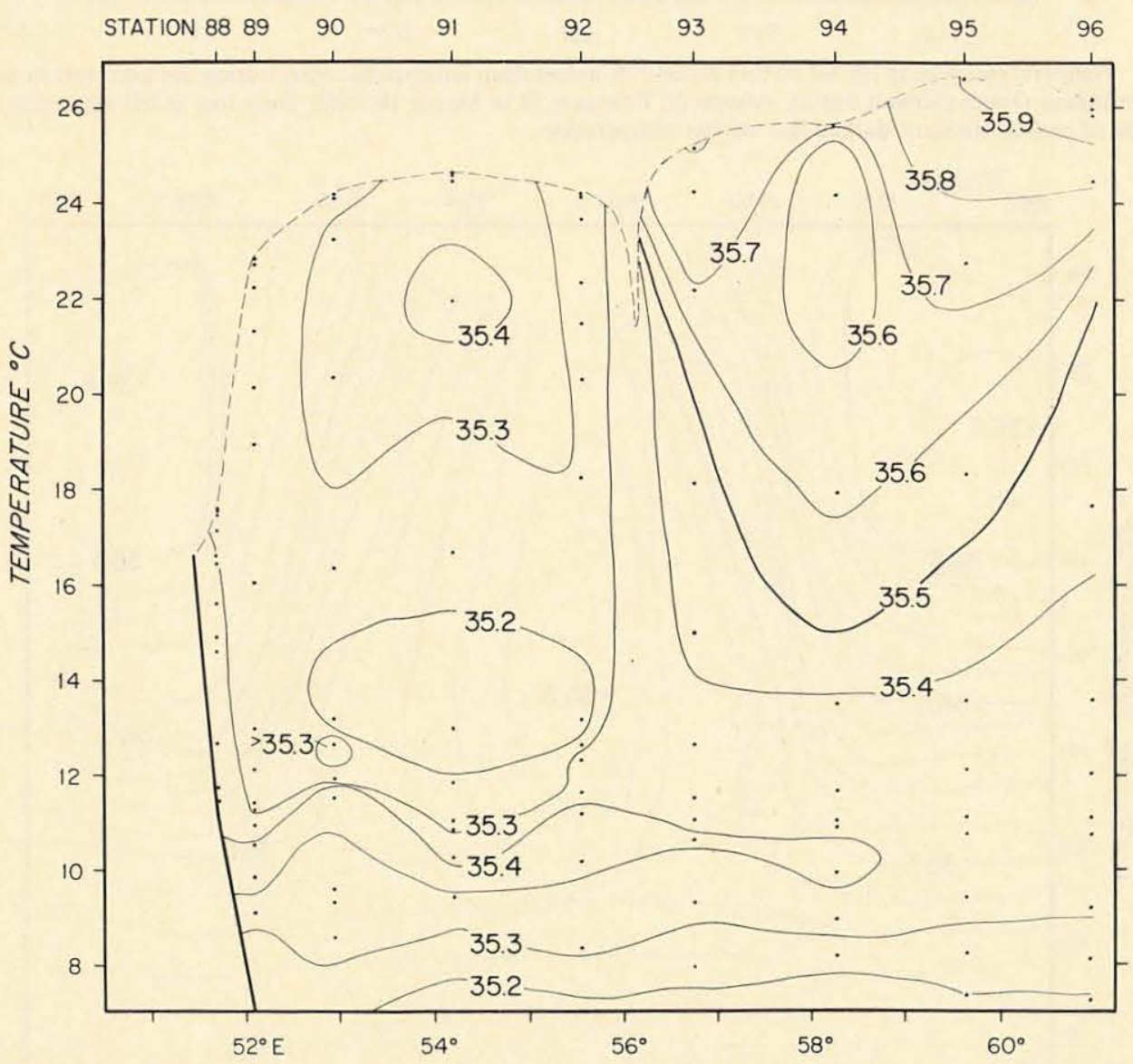

Fig. 1. Temperature-salinity (in $\%$ ) section along $10^{\circ} \mathrm{N}$ across anticyclonic eddies during the southwest monsoon in the western Indian Ocean (Somali Basin), Atlantis II, August 29 to September 1, 1963. Dark line lower left represents bottom temperature of coastal stations; dashed line surface temperature. 


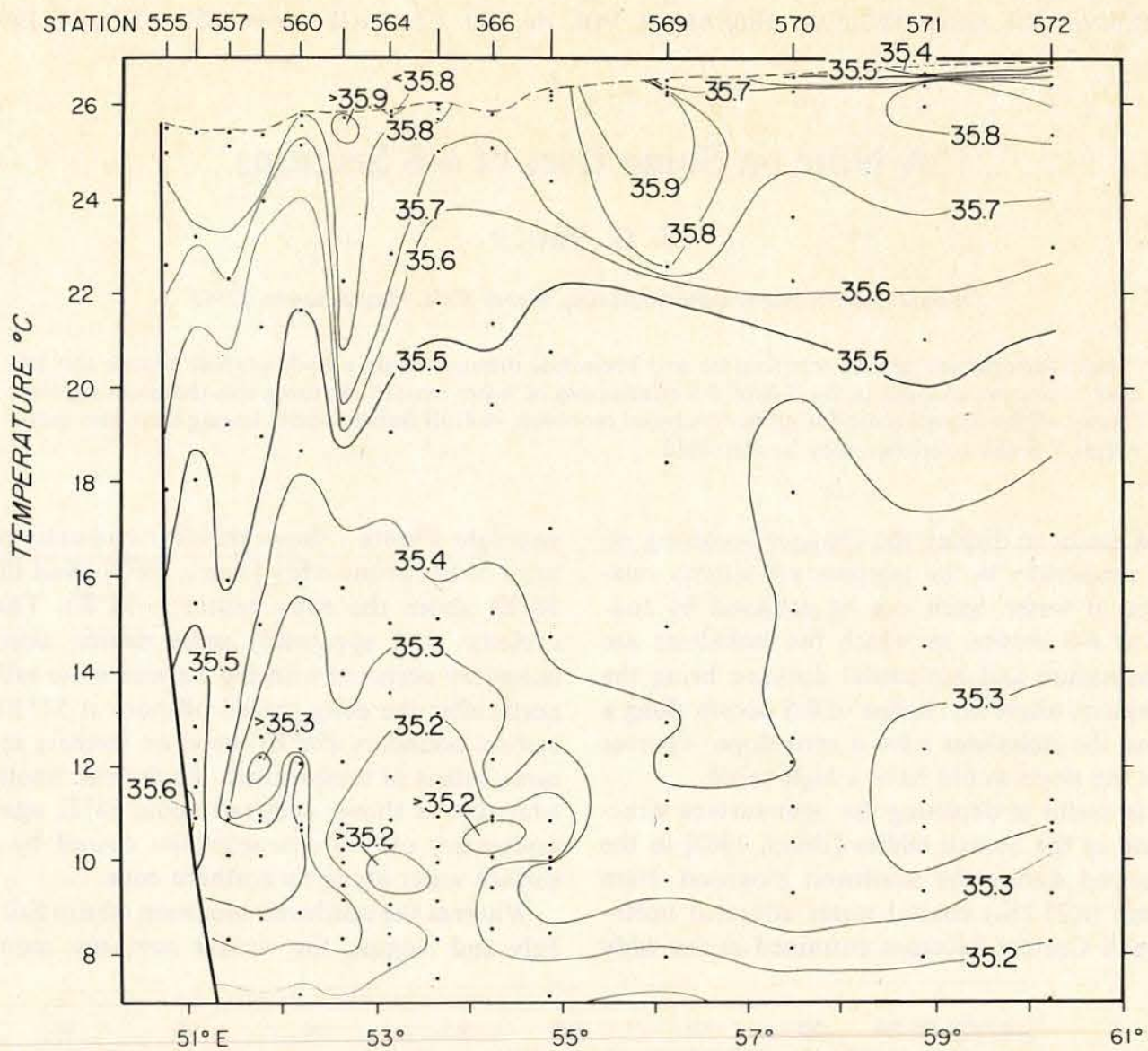

Fig. 2. Temperature-salinity (in \%o) section along $9^{\circ} \mathrm{N}$ across deep anticyclonic eddy during the northeast monsoon in the western Indian Ocean (Somali Basin), Atlantis II, February 28 to March 10, 1965. Dark line at left represents bottom temperature of coastal stations; dashed line surface temperature.

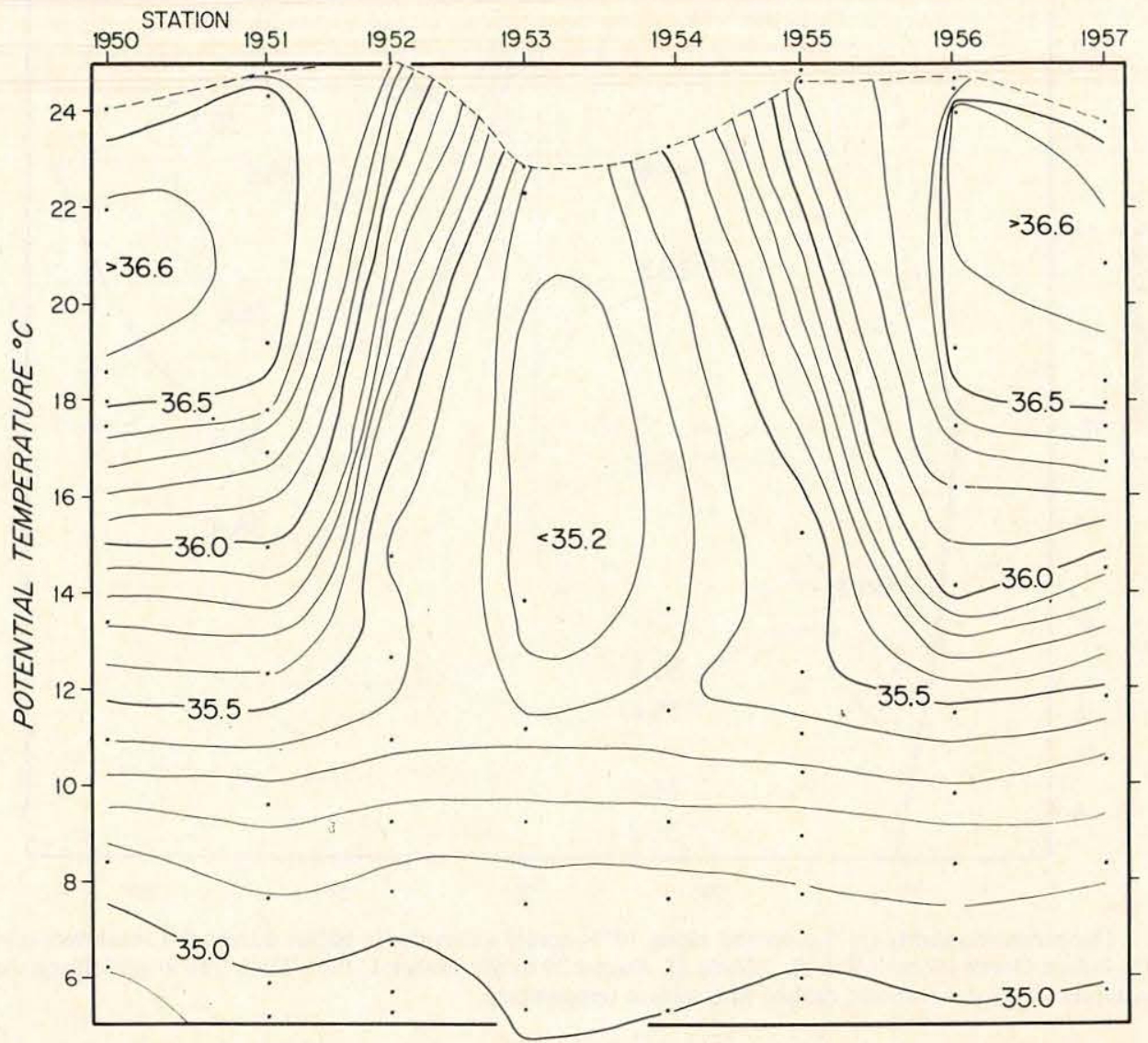

Fig. 3. Potential temperature-salinity (in \%) section from north (at $37^{\circ} 30^{\prime} \mathrm{N}$ ) to south (at $35^{\circ} 45^{\prime} \mathrm{N}$ ) along $66^{\circ} 40^{\prime} \mathrm{W}$ across Gulf Stream cyclonic ring (detached), Crawford, October 10-12, 1965. Dashed line represents surface temperature. 


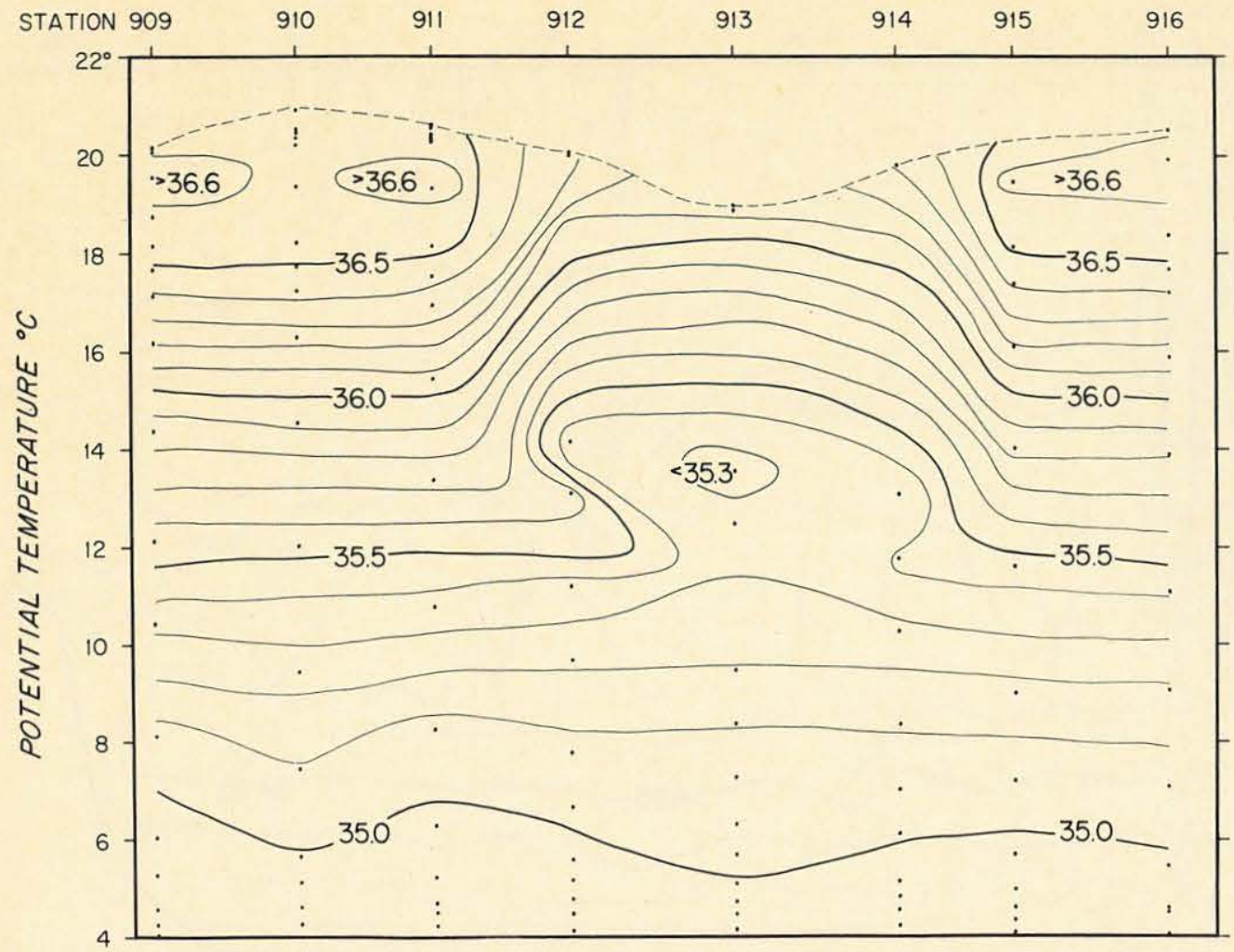

Fig. 4. Potential temperature-salinity (in \%o) section from north (at $37^{\circ} 29^{\prime} \mathrm{N}$ ) to south (at $35^{\circ} 44^{\prime} \mathrm{N}$ ) along $66^{\circ} 05^{\prime} \mathrm{W}$ across same Gulf Stream cyclonic ring 3 months later as shown in Figure 3, Atlantis II, January 11-12, 1966. Dashed line represents surface temperature.

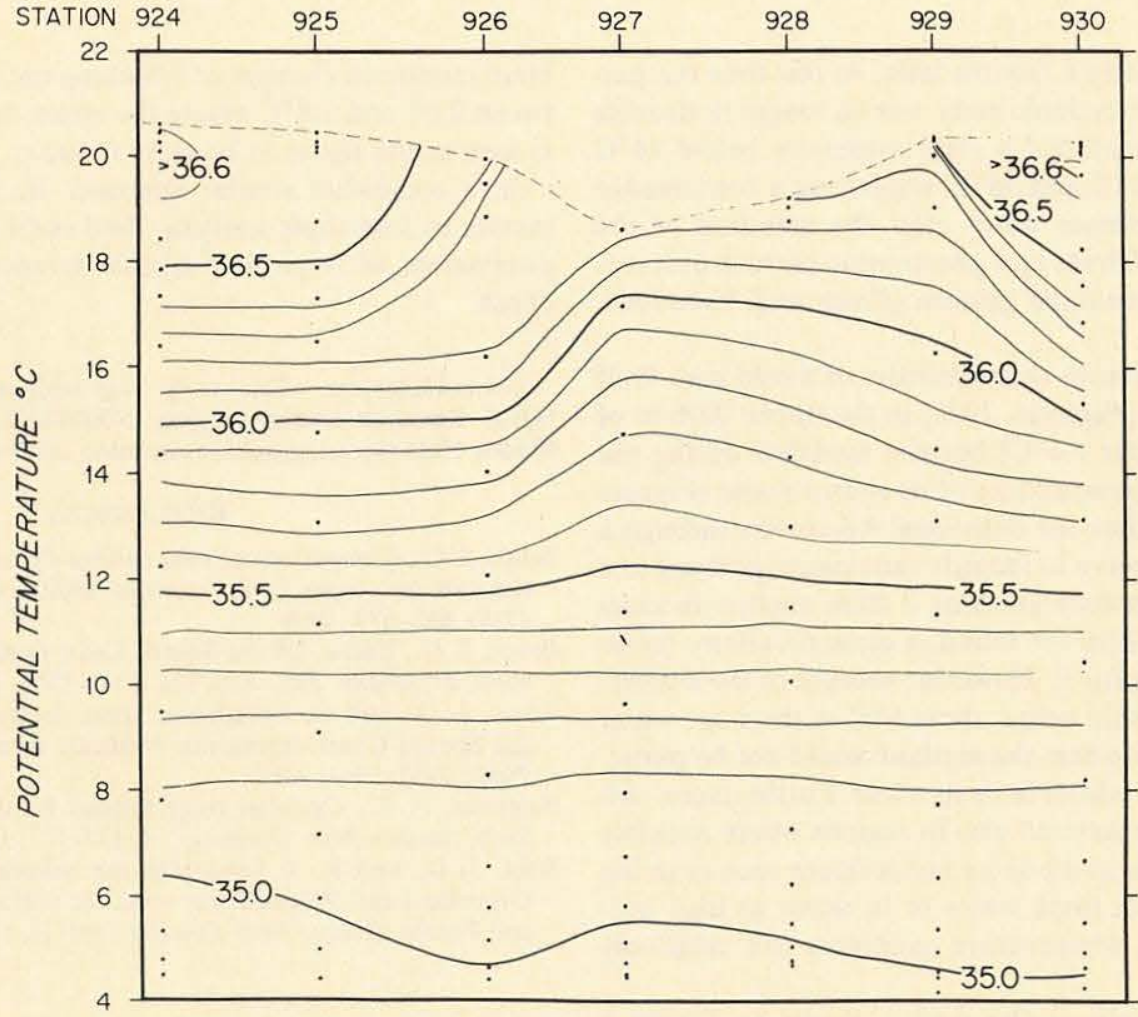

Fig. 5. Potential temperature-salinity (in \%o) section from north (at $37^{\circ} 04^{\prime} \mathrm{N}$ ) to south (at $35^{\circ} 36^{\prime} \mathrm{N}$ ) along $63^{\circ} 30^{\prime} \mathrm{W}$ across another Gulf Stream cyclonic ring separate from that in Figure 4 showing how isohalines would approach zero slope with increasing age of ring isolated in Sargasso Sea. Atlantis II, January 18-19, 1966. Dashed line represents surface temperature. 


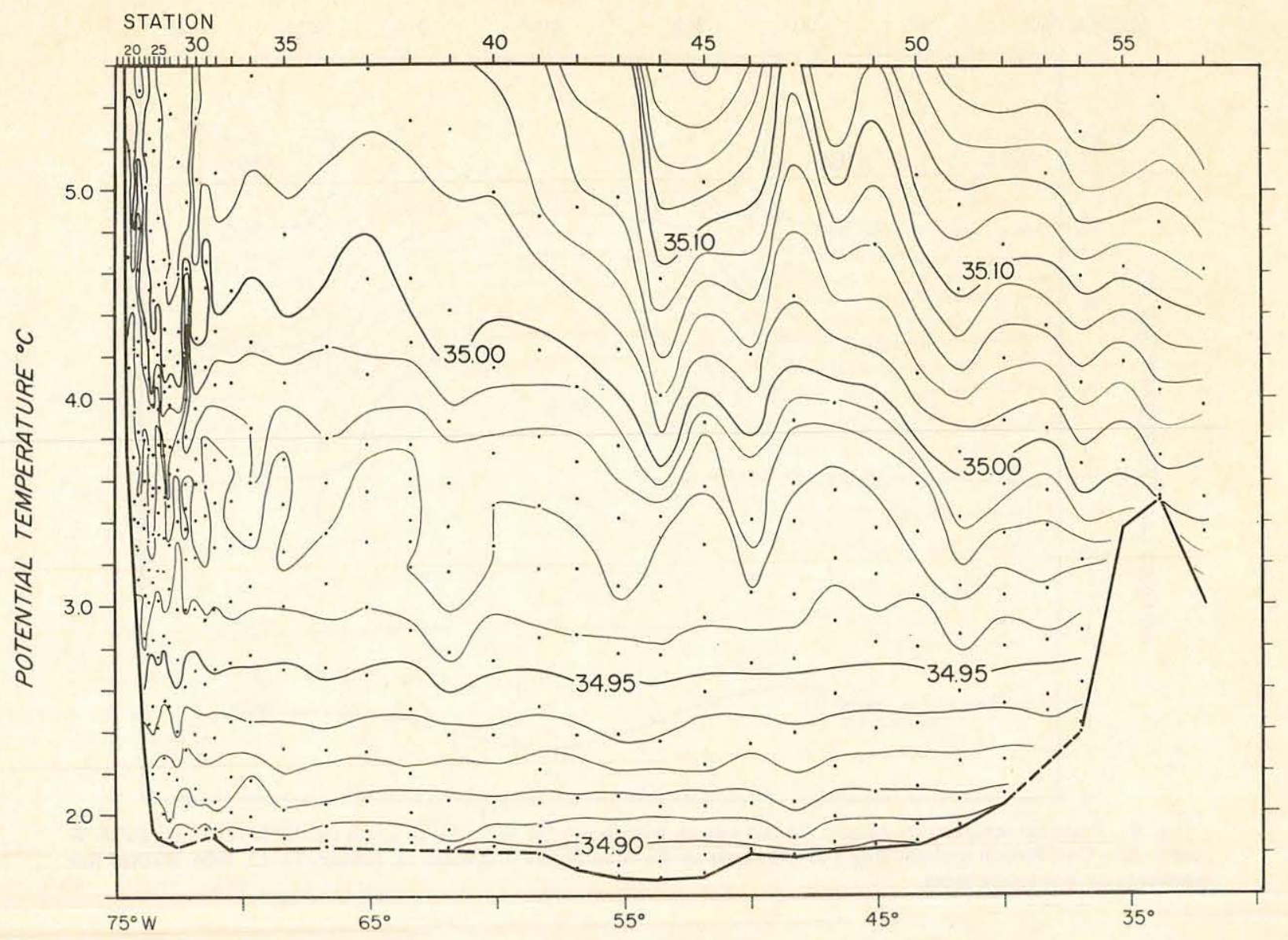

Fig. 6. Potential temperature-salinity (in \%o) section from west to east along $36^{\circ} 15^{\prime} \mathrm{N}$ for temperatures $<5.6^{\circ} \mathrm{C}$. Chain, April 19 to May 3, 1959.

maximum approximately 6 months later. At this time the pattern of the Somali anticyclonic eddy was no longer noticeable above $14^{\circ} \mathrm{C}$, but it exhibited a clear symmetry below $14^{\circ} \mathrm{C}$ (Figure 2) between $52^{\circ} \mathrm{E}$ and $56^{\circ} \mathrm{E}$, suggesting a continuance of the eddy in the deeper water after the cessation of the southwest monsoon. Direct and geostrophic current observations support this circulation pattern [Bruce and Volkmann, 1969].

The temperature-salinity characteristics of a cold core Gulf Stream cyclonic ring [Fuglister, 1972] in the upper $1000 \mathrm{~m}$ of the Sargasso Sea (water $>6^{\circ} \mathrm{C}$ ) become modified during the age of the eddy now independent of its source water (Figures 3 and 4). At any one time the individual $\theta$-S section through a single eddy can then serve to identify (analogous perhaps to a fingerprint) and aid in distinguishing it from another in cases where two or more eddies are found in close proximity (compare Figure 4 with Figure 5). However, because of the similarity of the $\theta$-S relationship below about $6^{\circ} \mathrm{C}$ of the slope water and that of the Sargasso Sea, the method would not be particularly useful for these eddies in deep water. Furthermore, difficulties would be encountered also in regions where multiple values of salinity occur at the same temperature such as in the upper North American slope water or in water at high latitudes where vertical temperature gradients are relatively weak.

On a large scale such as the section shown in Figure 6 across the North Atlantic, the method can be used to examine regions where relatively small changes occur in deep water.
Here minimum changes of $\theta$-S along the section are found between $2.0^{\circ}$ and $2.8^{\circ} \mathrm{C}$ where the mean slope of the isohalines is seen in the figure to be close to zero.

In a somewhat similar approach in studying deep water masses by isentropic analysis, Reid and Lynn [1971] have used parameters of $\sigma$ plotted against temperature, salinity, and depth.

Acknowledgment. This work was supported by the Office of Naval Research under contract N00014-79-C-0071, NR 083-004. Woods Hole Oceanographic Institution contribution number 4594.

\section{REFERENCES}

Bruce, J. G., Comparison of near surface dynamic topography during the two monsoons in the western Indian Ocean, Deep Sea Res., 15(6), 665-677, 1968.

Bruce, J. G., Eddies off the Somali Coast during the southwest monsoon, J. Geophy. Res., 85(C12), 7743-7748, 1979.

Bruce, J. G., and G. Volkmann, Some measurements of current off the Somali Coast during the northeast monsoon, J. Geophy. Res., 74(8), 1958-1967, 1969.

Fuglister, F. C., Cyclonic rings formed by the Gulf Stream 19651966, Studies Phys. Oceanogr., 1, 137-167, 1972.

Reid, J. L., and R. J. Lynn, On the influence of the NorwegianGreenland and Weddell seas upon the bottom waters of the Indian and Pacific oceans, Deep Sea Res., 18(11), 1063-1088, 1971.

(Received April 29, 1980; revised January 30, 1981; accepted February 2, 1981.) 
MANDATORY DISTRIBUTION LIST

FOR UNCLASSIFIED TECHNICAL REPORTS, REPRINTS, AND FINAL REPORTS PUBLISHED BY OCEANOGRAPHIC CONTRACTORS

OF THE OCEAN SCIENCE AND TECHNOLOGY DIVISION

OF THE OFFICE OF NAVAL RESEARCH

(REVISED NOVEMBER 1978)

1 Deputy Under Secretary of Defense (Research and Advanced Technology) Military Assistant for Environmental Science Room 3D129

Washington, D.C. 20301

Office of Naval Research

800 North Quincy Street

Arlington, VA 22217

3 ATTN: Code 483

1 ATTN: Code 460

2 ATTN: 102B

1 CDR Joe Spigai, (USN)

ONR Representative

Woods Hole Oceanographic Inst.

Woods Hole, MA 02543

Commanding Officer

Naval Research Laboratory

Washington, D.C. 20375

6 ATTN: Library, Code 2627

12 Defense Technical Information Center

Cameron Station

Alexandria, VA 22314

ATTN: DCA

Commander

Naval Oceanographic Office

NSTL Station

Bay St. Louis, MS 39522

1 ATTN: Code 8100

1 ATTN: Code 6000

1 ATTN: Code 3300

1 NODC/NOAA

Code D781

Wiscons in Avenue, N.W. Washington, D.C. 20235

1 Mr. Michael H. Kelly

Administrative Contracting Officer

Department of the Navy

Office of Naval Research

Eastern/Central Regional Office

Building 114, Section D

666 Summer Street

Boston, MA 02210 


\begin{tabular}{|c|c|}
\hline REPORT DOCUMENTATION PAGE & $\begin{array}{c}\text { READ INSTRUCTIONS } \\
\text { BEFORE COMPLETING FORM }\end{array}$ \\
\hline \begin{tabular}{l|l} 
1. REPORT NUMBER & 2. GOVT ACCESSION NO \\
WHOI $-81-80$ &
\end{tabular} & 3. RECIPIENT'S CATALOG NUMBER \\
\hline $\begin{array}{l}\text { 4. TITLE (and Subtito) } \\
\text { A NOTE ON SOME USES OF } \theta \text {-S SECTIONS }\end{array}$ & $\begin{array}{l}\text { 5. TYPE OF REPORT \& PERIOD COVERED } \\
\text { Technical }\end{array}$ \\
\hline & $\begin{array}{l}\text { 6. PERFORMING ORG. REPORT NUMBER } \\
\text { WHOI Contr. } 4594\end{array}$ \\
\hline 7. $A U T H O R(a)$ & 8. CONTRACT OR GRANT NUMBER(o) \\
\hline J. G. Bruce & N00014-79-C-0071 \\
\hline $\begin{array}{l}\text { 9. PERFORMING ORGANIZATION NAME AND ADDRESS } \\
\text { Woods Hole Oceanographic Institution } \\
\text { Woods Hole, Massachusetts } 02543\end{array}$ & $\begin{array}{l}\text { 10. PROGRAM ELEMENT. PROJECT, TASK } \\
\text { AREA A WORK UNIT NUMBERS } \\
\text { NR } 083-004\end{array}$ \\
\hline $\begin{array}{l}\text { 11. CONTROLLING OFFICE NAME AND ADDRESS } \\
\text { NORDA/National Space Technology Laboratory } \\
\text { Bay St. Louis, MS } 39529\end{array}$ & $\begin{array}{l}\text { 12. REPORT DATE } \\
\text { Sept. } 1981 \\
\text { 13. NUMBER OF PAGES }\end{array}$ \\
\hline 14. MONITORING AGENCY NAME \& ADORESS(it different from Controlling Oflice) & $\begin{array}{l}\text { 15. SECURITY CLASS. (of thio roport) } \\
\text { UnClassified } \\
\text { 15. DECLASIIFICATION/DOWNGRADING } \\
\text { SCHEDULE }\end{array}$ \\
\hline \multicolumn{2}{|l|}{$\begin{array}{l}\text { 16. DISTRIBUTION STATEMENT (of thlo Roport) } \\
\text { Approved for public release; distribution unlimited. }\end{array}$} \\
\hline \multicolumn{2}{|c|}{ 17. DISTRIBUTION STATEMENT (of the abstract ontered in Block 20, If different from Roport) } \\
\hline \multirow{2}{*}{\multicolumn{2}{|c|}{$\begin{array}{l}\text { 18. SUPPLEMENTARY NOTES } \\
\text { Reprinted from: Journal of Geophysical Research } 86(\mathrm{C} 7) \text { : 6649-6652 (July 20, } \\
\text { 1981). }\end{array}$}} \\
\hline & \\
\hline \multicolumn{2}{|l|}{$\begin{array}{l}\text { 19. KEY WORDS (Continuo on roveroe oide if nocosoary and Identity by block numbor) } \\
\text { 1. Water mass identification } \\
\text { 2. Temperature-salinity characteristics } \\
\text { 3. Eddy structure off Somalia and in Sargasso Sea }\end{array}$} \\
\hline \multicolumn{2}{|c|}{$\begin{array}{l}\text { 20. ABSTRACT (Conthue on rovoroo aldo if nocosoary and ldentity by block numbor) } \\
\text { Isohalines plotted against temperature and horizontal distance along } \\
\text { a hydrographic section can be used to observe changes in the T-S or } \theta-S \\
\text { relationship of water masses. By using this technique, eddies formed off } \\
\text { the Somali coast during the southwest monsoon, or Gulf Stream eddies having } \\
\text { their own individual T-S characteristics, may be identified. }\end{array}$} \\
\hline
\end{tabular}




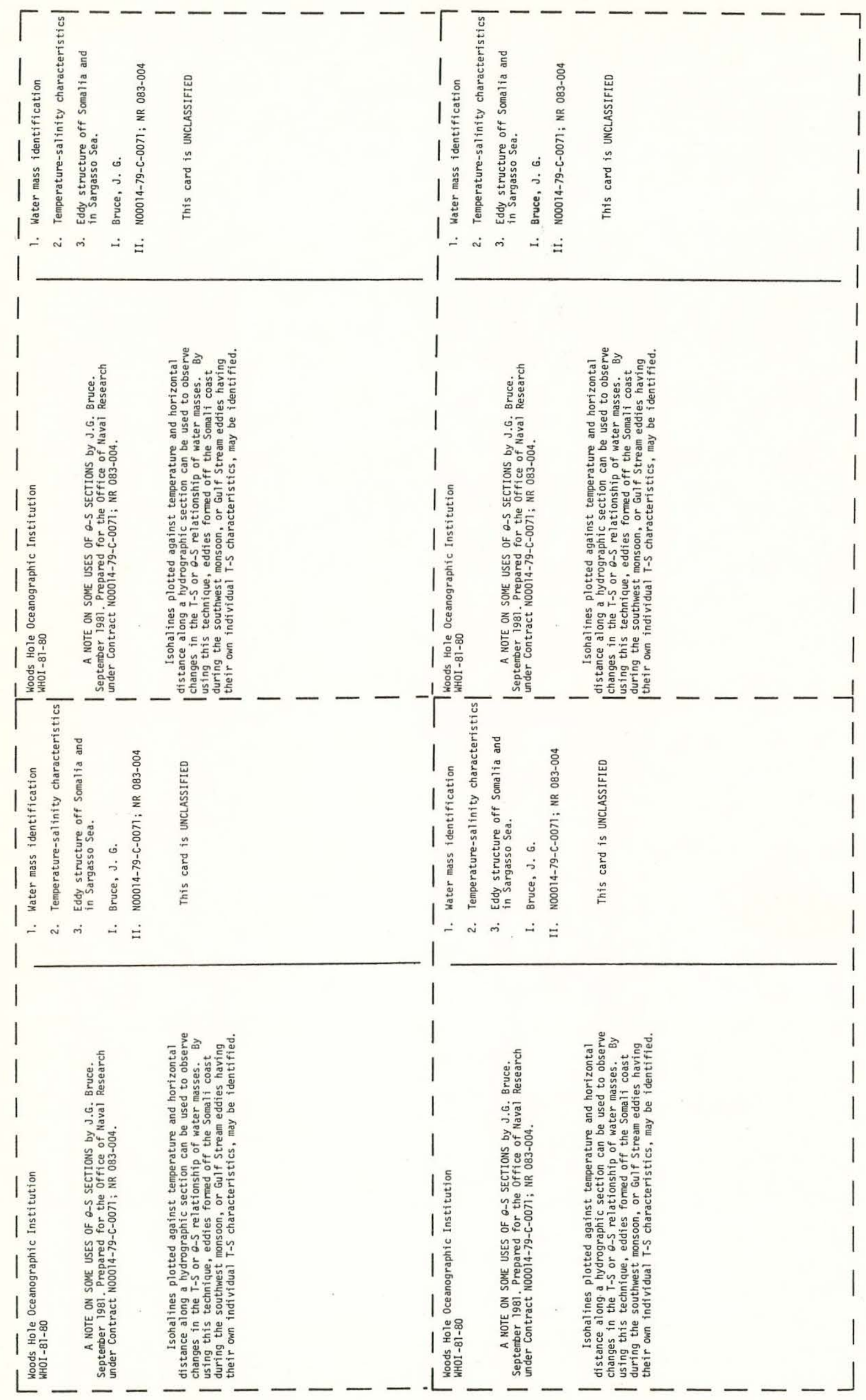

